\title{
A Matter of Public Concern: The First Amendment and Equal Employment for LGBT Educators
}

\section{Karen Graves}

The history of antigay discrimination in schools underscores the notion that who is speaking can be perceived as much of a threat to heteronormativity as what is being said. Suppressing gay bodies has been the most severe means of censoring expressions of sexuality, illustrated in Cold War-era purges of professors, teachers, school officials, and students. ${ }^{1}$ In the 1970s an expanding gay rights movement disrupted this most forceful period of repression, and battles over lesbian, gay, bisexual, transgender (LGBT) teacher employment shifted to the courts and statutory terrain. $^{2}$ At that point, LGBT teachers based their defense against loss of employment upon First Amendment freedom of speech and Fourteenth Amendment equal-protection claims. The logic of these constitutional arguments, however, failed to "adequately guarantee gay men and lesbians that they may 'dare speak their names," prompting one scholar to assert, "the central liberty at stake is the liberty to represent oneself as gay or lesbian in the public sphere." Indeed, it is hard to imagine taking

Karen Graves (graves@denison.edu) is Professor and Chair in the Department of Education at Denison University. She is author of And They Were Wonderful Teachers: Florida's Purge of Gay and Lesbian Teachers. She would like to thank Joy Williamson-Lott for comments on drafts of the essay.

${ }^{1}$ See, for example, Jackie M. Blount, Fit to Teach: Same-Sex Desire, Gender, and School Work in the Twentieth Century (Albany: State University of New York Press, 2005); Karen L. Graves, And They Were Wonderful Teachers: Florida's Purge of Gay and Lesbian Teachers (Urbana: University of Illinois Press, 2009); Karen Marie Harbeck, Gay and Lesbian Educators: Personal Freedoms, Public Constraints (Malden, MA: Amethyst Press, 1997); Margaret A. Nash and Jennifer A. R. Silverman, "'An Indelible Mark': Gay Purges in Higher Education in the 1940s," History of Education Quarterly 55, no. 4 (Nov. 2015), 441-59; and Kathleen Weiler, "The Case of Martha Deane: Sexuality and Power at Cold War UCLA," History of Education Quarterly 47, no. 4 (Winter 2007), 470-96.

${ }^{2}$ In this analysis, I use lesbian, gay, bisexual, transgender, LGBT, and, in some instances, homosexual, rather than queer, to identify educators challenging gay discrimination in schools. These terms all represent complex identities. My word choice reflects the language used in the period under analysis.

${ }^{3}$ Cheshire Calhoun, Feminism, the Family, and the Politics of the Closet: Lesbian and Gay Displacement (Oxford, UK: Oxford University Press, 2000), 94-95. 
advantage of constitutional protections without some measure of visibility, a condition that traps LGBT educators in a double bind. The freespeech defense requires that the speech in question addresses a matter of public concern. Yet educators generally have been inclined to keep sexual identity private in order to avoid both exposure to deep-seated prejudice in school communities and dismissal. While scholars have noted this dilemma in the expanding literature of LGBT education history, an analysis of two cases that reached the United States Supreme Court in 1985 may refine our understanding of the logic and limitations of constitutional arguments used on behalf of LGBT educators in the late twentieth century.

It is, of course, impossible to disentangle LGBT teachers' longlasting fight for equal employment rights from the larger gay rights movement. The historical record plies individual acts of courage, personal and professional integrity combined with increasing organizational support for teachers, the latest research findings on sexuality, and emergent laws and policies that extended civil rights to LGBT Americans. ${ }^{4}$ Individual educators who decided to challenge unfair dismissals in court secured more stable legal positions and drew strength from the early gains of the gay rights movement, just as their example brought attention to what was at stake in the political moment. These teachers and guidance counselors, like other educators before them who confronted other forms of job discrimination, navigated between professional and public pulls. Resisting removal from the profession, they staked a claim for academic freedom and modeled a form of free inquiry for students. As public employees, their work was open to exposure as a matter of course; as public employees in the field of education, their lives fell under scrutiny as well..$^{5} \mathrm{~A}$ brief overview illustrates how individual court cases and broader efforts to ban LGBT teachers from the profession braided through this historical trajectory. Following the thread of any particular case, one is reminded of how long and arduous a civil court case can be, and how hard it has been for educators to claim legal ground on this issue.

\footnotetext{
${ }^{4}$ See Blount, Fit To Teach; Gillian Frank, “'The Civil Rights of Parents': Race and Conservative Politics in Anita Bryant's Campaign against Gay Rights in 1970s Florida," Journal of the History of Sexuality 22, no. 1 (Jan. 2013), 126-60; Fred Fejes, Gay Rights and Moral Panic: The Origins of America's Debate on Homosexuality (New York: Palgrave Macmillan, 2008); Karen Graves, "Political Pawns in an Educational Endgame: Reflections on Bryant, Briggs, and Some TwentiethCentury School Questions," History of Education Quarterly 53, no. 1 (Feb. 2013), 1-20; Harbeck, Gay and Lesbian Educators; and Catherine A. Lugg, US Public Schools and the Politics of Queer Erasure (New York: Palgrave Macmillan, 2016).

${ }^{5}$ See my discussion of this point in Graves, And They Were Wonderful Teachers, $120-143$.
} 
Historians credit homophile groups such as the Mattachine Society and the Daughters of Bilitis for igniting the gay rights movement in the 1950s. Their efforts to counter stereotypes and assimilate homosexuals into public life tangled with other activists representing gay bar culture who asserted a bold claim to visibility. Together, these streams effected a shift in the legal tide. ${ }^{6}$ In 1961, Illinois became the first state to decriminalize homosexuality, a critical correction to the earlier legal code that barred LGBT educators (statutory felons in violation of sodomy laws) from working in public schools. In 1966, the American Civil Liberties Union moved beyond free-speech and due-process claims to defend LGBT rights, adopting a more explicit antidiscriminatory stance based on the right to privacy. ${ }^{7}$ In 1973, the American Psychiatric Association removed homosexuality from its list of mental illnesses, eliminating another argument against employing LGBT educators, and the National Education Association passed a resolution the next year opposing discrimination on the basis of sexuality. Riding the crest of these victories, LGBT advocates adopted a preemptive legal posture. By 1977, forty cities and counties in the United States had passed laws prohibiting discrimination against gay men and lesbians in employment, housing, and public accommodations.

Even as civil rights activists were dismantling institutional mechanisms that classified LGBT people as criminals or diseased, long-standing notions regarding the presumed immorality of homosexuality proved more difficult for educators to address. In a case that originated in 1963, the California Supreme Court eventually determined that homosexual conduct did not make a teacher unfit, but it allowed a teacher's dismissal to stand if the behavior many perceived as immoral became public knowledge. In 1971, Peggy Burton became the first LGBT teacher to file a federal civil rights suit for undue dismissal; school officials had fired her for admitting she was a "practicing homosexual." An Oregon District Court struck down as unconstitutionally vague the immorality statute school officials cited, but Burton was an untenured teacher and-absent any equal protection ruling by the courts - had no further leverage to reclaim her job. Years later the Fourth Circuit Court upheld a Maryland teacher's First

\footnotetext{
${ }^{6}$ Nan Alamilla Boyd, Wide-Open Town: A History of Queer San Francisco to 1965 (Berkeley: University of California Press, 2003).

${ }^{7}$ It would take over four decades for the United States Supreme Court to strike down sodomy laws across the nation. See Lawrence v. Texas, 539 U.S. 558 (2003); "ACLU History: Earliest Advocacy on Behalf of LGBT People," American Civil Liberties Union, https://www.aclu.org/other/aclu-history-earliest-advocacybehalf-lgbt-people; and Samuel Walker, In Defense of American Liberties: A History of the ACLU (Carbondale: Southern Illinois University Press, 1999), 312.
} 
Amendment right to free speech, overturning a district court ruling that homosexuals could teach in public schools only if they stayed closeted. The district court deemed that a teacher's public advocacy of gay rights possessed an "inflammatory character ... deleterious to the educational process." 8 He was not reappointed, however, on an unrelated technicality. In another case the New Jersey Superior Court found that school boards maintained wide latitude in determining the fitness of gay teachers, and the Supreme Court of Washington ruled that homosexual status alone was enough to find a teacher unfit on the basis of immorality. ${ }^{9}$

Because regulations governing public schools are rooted in state law and local policy, federal courts have tended to allow school officials a great deal of leeway in making personnel decisions. LGBT educators stood to gain, then, by organized efforts against employment discrimination that swept the nation in the 1970s. Ironically, they became the foil for conservative activists who worked to revoke the new antidiscrimination measures. Following the lead of Anita Bryant's 1977 "Save Our Children" crusade in Miami, antigay protesters targeted teachers in their political rhetoric and overturned antidiscrimination ordinances in St. Paul, Minnesota; Wichita, Kansas; and Eugene, Oregon. Going further, state senators John Briggs and Mary Helm proposed similar measures in California and Oklahoma, respectively, that would bar gay men and lesbians from teaching in public schools. In a spectacular political moment in 1978, California voters defeated Briggs's referendum by a sixteen-point margin. Stung by the recent defeat in Miami, LGBT activists worked effectively with a wide coalition of allies against Brigg's far-reaching initiative. Helm's bill, however, passed in the Oklahoma House $88-2$ and by a unanimous vote in the Senate.

As the decade came to a close, LGBT teachers mobilized on two legal fronts: continuing the fight against discrimination on a case-bycase basis and challenging the newly adopted state law that kept them out of the profession. LGBT teachers in the 1980s sued school districts for violating their First and Fourteenth Amendment rights. Marjorie Rowland, fired by the Mad River School District in Ohio in 1974, pursued her case until it finally reached a district court in 1981. In a case

${ }^{8}$ Acanfora v. Board of Education of Montgomery County, 359 F. Supp. 843 (D. Md. 1973), at 857.

${ }^{9}$ See Erin Rook, "Queer Heroes NW: Peggy Burton," PQ Monthly, June 18, 2012, http://www.pqmonthly.com/queer-heroes-nw-peggy-burton/4317; Joyce Murdoch and Deb Price, Courting Justice: Gay Men and Lesbians v. the Supreme Court (New York: Basic Books, 2001), 176-98; Blount, Fit To Teach, 114-20; and Harbeck, Gay and Lesbian Educators, 248-69. 
challenging state law, the National Gay Task Force (NGTF) sued the state of Oklahoma to repeal what they considered to be a vague and overly broad law that allowed districts to fire LGBT teachers. While both cases turned in large part on free-speech claims, it is apparent that who was speaking was a significant element in the divergent outcomes.

A district court found that Mad River School District had violated Rowland's First and Fourteenth Amendment rights when it dismissed her on the basis of her bisexuality. Space constraints do not allow for a full discussion of the case's complexities, but it is important to note that the judge's decision to issue fifty-six special verdict forms to the jury played a role in the surprising outcome in Rowland's favor. Special verdicts focus deliberation on disputed facts of the case rather than asking a jury to determine guilt or liability. A series of special verdicts enables the judge to "connect the dots" and issue a final ruling aligned with the jury's findings.

When the jury found that Rowland's speech acknowledging her sexuality had not disrupted the school environment, school attorneys tried a new tack: they charged that Rowland's speech was not protected because she was not speaking on a matter of public concern. The judge dismissed this argument, noting that educators have the right to express personal thoughts and feelings as long as the school function is not inhibited.

In 1984, the Sixth Circuit Court overturned Rowland's victory. The dissenting judge argued that school administrators' own actions to remove Rowland from her duties - based on fear of negative public reaction-was evidence that her speech addressed a matter of public concern. The majority, however, ruled that Rowland's initial request that coworkers hold her bisexual status in confidence indicated that her speech was addressing a private matter. As such, it was not protected by the First Amendment.

Meanwhile, the NGTF case was making its way through the lower courts. A district court judge upheld the two-part Oklahoma law that prohibited both "public homosexual activity" (barring LGBT teachers from employment) and "public homosexual conduct" (prohibiting all teachers from discussing LGBT issues). A divided appellate court struck down the part of the law prohibiting "public homosexual conduct," noting that statements "aimed at legal and social change, are at the core of First Amendment protections." ${ }^{10}$ Because the appellate court had not struck down the part of the law that kept LGBT educators out of schools, the only question the Supreme Court considered was the broader one regarding advocacy speech.

${ }^{10}$ National Gay Task Force v. Board of Education of the City of Oklahoma City, 729 F.2d 1270 (10th Cir. 1984). 
The school district's attorney, Dennis Arrow, argued that the state interest in citizenship training and preserving traditional values outweighed the interests of teachers who might advocate for gay rights: "Because of the ... threat to student morality, to proper traditional cultural values, ... [to] effectiveness of teacher performance in the classroom ... we think therefore that all of the goals of public education may be threatened by teacher advocacy of this specific crime." 11 Laurence Tribe, the attorney representing the NGTF, countered, "Public school teachers have First Amendment rights every bit as broad as private citizens when they talk on matters of public interest, whether they are talking politics or philosophy or ethics or social change." ${ }^{2}$ According to existing legal precedent, a teacher claiming free-speech protection needed to show that the speech addressed a matter of public concern, that the speech did not interfere with one's official duties, and that the teacher was speaking as a private citizen. ${ }^{13}$ Justice Lewis Powell took no part in the case due to illness, and the remaining eight justices split evenly, upholding First Amendment protections as a matter of public concern for teachers who speak about gay rights. ${ }^{14}$ Reading this case in juxtaposition with Rowland's, however, one questions whether the freedom to speak extended to all teachers equally.

One month after the Supreme Court heard arguments in the NGTF case, it denied Rowland's petition for a writ of certiorari. Had Rowland been a straight teacher in Oklahoma, her right to free speech would have been protected. Once her bisexual identity became public knowledge, however, the court stripped her of First Amendment rights, charging that she was speaking on a private matter. As one scholar observes, "Having once attempted to keep her bisexuality secret, Rowland could never join a public discourse about her own dismissal. ... But the chain of events that led to Rowland's dismissal ... demonstrates that the disclosure of homosexual identity, no matter how secretive, is always a political act [emphasis in the original]." 15

\footnotetext{
${ }^{11}$ Dennis W. Arrow, Oral Argument, Board of Ed. of Oklahoma City v. National Gay Task Force, 470 US 903 (1985).

${ }^{12}$ Laurence H. Tribe, Oral Argument, Board of Ed. of Oklahoma City v. National Gay Task Force, at 45 minutes, 39 seconds.

${ }^{13}$ Matthew Feda, "Public Employees and Free Speech," Labor \& Employment 49, no. 3 (Dec. 2011), https://www.isba.org/sections/laboremploymentlaw/newsletter/ 2011/12/publicemployeesandfreespeech.

${ }^{14}$ See Karen Graves, "Sexuality," in Miseducation: A History of Ignorance-Making in America and Abroad, ed. A. J. Angulo (Baltimore, MD: Johns Hopkins University Press, 2016), 52-72.

${ }^{15}$ Janet E. Halley, "The Politics of the Closet: Legal Articulation of Sexual Orientation Identity," in After Identity: A Reader in Law and Culture, ed. Dan
} 
In his dissent to the Supreme Court decision not to accept Rowland's case (joined by Justice Marshall), Justice William Brennan affirmed that Rowland had been fired due to her bisexual status and wrote that her case raised substantial First Amendment claims. Taking issue with what he dismissed as shoddy thinking by the Sixth Circuit Court, Brennan asserted that Rowland's speech regarding her sexual identity was protected because she had not disrupted the workplace. Probably more importantly for gay rights advocates, Brennan also defined the content of Rowland's speech as a matter of public concern. He argued that it was impossible not to see that the country was deeply engaged in public debate on gay rights.

Brennan then went further, suggesting that suspect status might apply to homosexuals, a legal classification that would make it easier to claim equal protection under the law:

Because of the immediate and severe opprobrium often manifested against homosexuals once so identified publicly, members of this group are particularly powerless to pursue their rights openly in the political arena. Moreover, homosexuals have historically been the object of pernicious and sustained hostility, and it is fair to say that discrimination against homosexuals is "likely ... to reflect deep-seated prejudice rather than ... rationality". ${ }^{16}$

While LGBT citizens have yet to claim suspect classification, Brennan's logic still resounds in the legal sphere. ${ }^{17}$

Freedom of speech protections remain critical for LGBT educators. "By disciplining Rowland," legal scholar William Eskridge explains, "Mad River was seeking to silence and close off debate about proper sexuality - the antithesis of the first amendment's aspiration toward 'uninhibited, robust, wide-open' debate on public issues." ${ }^{18}$ For many, First Amendment violations are especially egregious when they occur in schools, presumably institutions dedicated to free thought and the pursuit of inquiry.

Danielsen and Karen Engle (New York: Routledge, 1995), 36. Rowland first disclosed her bisexual identity to another staff member in a professional capacity, as she was counseling two students who were coming to terms with their own sexual identities. Rowland's attorneys also made a case that her dismissal violated the constitutional right to privacy, but the court did not address this claim.

${ }^{16}$ Rowland v. Mad River Local School Dist., 470 U.S. 1009 (1985), at 1014.

${ }^{17}$ See Karen Graves and Margaret A. Nash, "Staking a Claim in Mad River: Advancing Civil Rights for Queer America," in Principles of Resistance: How Teachers Resolve Ethical Dilemmas, ed. Lizabeth Cain and Doris A. Santoro (Cambridge, MA: Harvard Education Press, forthcoming).

${ }^{18}$ William N. Eskridge Jr., Gaylaw: Challenging the Apartheid of the Closet (Cambridge, MA: Harvard University Press, 1999), 180. 
There are, however, moral and pragmatic issues to consider in relying too narrowly on a First Amendment defense. Philosopher Cheshire Calhoun offers a thought-provoking argument, framed by a focus on the ways in which LGBT people are displaced outside civil society. Rather than being subordinated within society in ways similar to gender and racial oppression, Calhoun argues that LGBT people have stood outside public, private, and future spheres altogether. The displacement occurs as a result of "the requirement that all citizens adopt at least the appearance of a heterosexual identity as a condition of access to the public sphere. ... This, in effect, displaces gay and lesbian identities from the public sphere [emphasis in original]." ${ }^{19}$ Lacking recognition in the public sphere has meant, among other things, that LGBT people have had "no claim to being mentionable - to being public-except under social conditions that make their mention a political, public, and debated subject [emphasis in original]." ${ }^{20}$ It follows that to enter the public sphere under these conditions, LGBT citizens are present only as "debatable speakers.... Once publicly proclaimed, there will be no social immunity from public scrutiny and public criticism [emphasis in original]." ${ }^{21}$ In simpler terms, everyone has a claim on free speech, including politicians, school officials, and community members who cast LGBT educators as immoral beings, unfit to teach. In order to secure academic freedom in one of its most basic forms, access to employment, LGBT advocates cannot rely on freedom of speech arguments alone. Put simply, if the validity of my visibility in the workplace rests only upon speech you can challenge, a free-speech argument can just as easily be used to dismiss or even erase me.

Reviewing the arguments at the core of Rowland v. Mad River and Board of Education v. NGTF has heightened my awareness of the subtle distinctions among free-speech claims on behalf of teachers. There is something to celebrate in the 1985 victory for teachers' free speech, however slim. We should also be aware that using the First Amendment to carve out space for LGBT people to speak their piece and claim their identities won't be enough to offset discrimination within a raucous public square. Nonetheless, it remains a fundamental principle in the constellation of constitutional rights to assemble, speak, and claim due process and equal protection. Academic freedom that guards against the displacement of LGBT educators is consistent with this most important public concern.

doi: $10.1017 /$ heq.2018.23

\footnotetext{
${ }^{19}$ Calhoun, Feminism, the Family, and the Politics of the Closet, 76.

${ }^{20}$ Calhoun, Feminism, the Family, and the Politics of the Closet, 94.

${ }^{21}$ Calhoun, Feminism, the Family, and the Politics of the Closet. 94.
} 